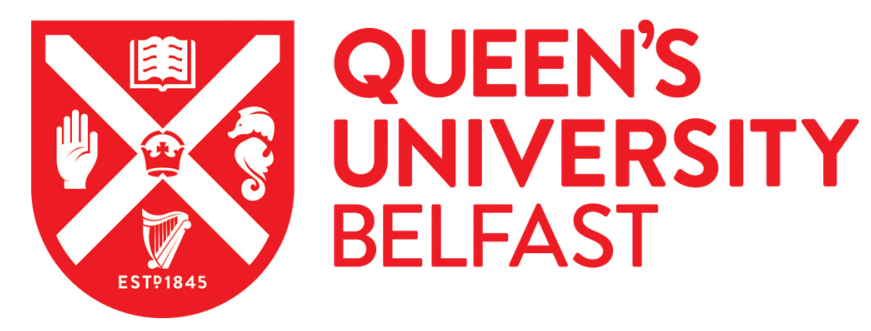

\title{
'For the Improvement and Amusement of Young Ladies': Elizabeth Carter and the Bluestockings in Ireland
}

Haslett, M. (2018). 'For the Improvement and Amusement of Young Ladies': Elizabeth Carter and the Bluestockings in Ireland. Eighteenth-Century Ireland, 33, 33-60.

\author{
Published in: \\ Eighteenth-Century Ireland
}

Document Version:

Peer reviewed version

Queen's University Belfast - Research Portal:

Link to publication record in Queen's University Belfast Research Portal

Publisher rights

(c) 2018 Eighteenth-Century Ireland Society.

This work is made available online in accordance with the publisher's policies. Please refer to any applicable terms of use of the publisher.

\section{General rights}

Copyright for the publications made accessible via the Queen's University Belfast Research Portal is retained by the author(s) and / or other copyright owners and it is a condition of accessing these publications that users recognise and abide by the legal requirements associated with these rights.

Take down policy

The Research Portal is Queen's institutional repository that provides access to Queen's research output. Every effort has been made to ensure that content in the Research Portal does not infringe any person's rights, or applicable UK laws. If you discover content in the Research Portal that you believe breaches copyright or violates any law, please contact openaccess@qub.ac.uk. 
'For the Improvement and Amusement of Young Ladies': Elizabeth Carter and the Bluestockings in Ireland

MOYRA HASLETT

In 1772, the Waterford printers Hugh and James Ramsey printed a collection of poems entitled Select Poems, Designed for the Improvement and Amusement of Young Ladies. By Miss Carter and Others, which consisted of ninety-six pages of an uncommon sextodecimo oblong format, measuring $10 \times 11 \mathrm{~cm}$ bound (see image 1). ${ }^{1}$ With its explicit appeal to young ladies, the book was evidently one of the growing number of books published specifically for children and young adults in the later eighteenth century and its attractive setting and presentation suggest that it was a book of value for the daughters of elite and aspirant middling class families. It is appealingly presented throughout with well-designed pages, generous margins and spacing, and 23 printers' ornaments, remarkably few of which are repeated. The decorative headpiece of the first page appropriately resembles practice embroidery stitches and is mirrored in a simple but elegant initial factotum for the collection's first capital letter (image 2). ${ }^{2}$ And throughout the book, the separation of poems is indicated by constantly varying printers' ornaments (see images 3 and 4). Although no

\footnotetext{
I am grateful to Andrew Carpenter and Amy Prendergast, and to the two anonymous reviewers for the journal, for contributing suggestions and corrections in my preparation of the published version of this essay, a portion of which was delivered at the Eighteenth-Century Ireland Society annual conference in Waterford (June 2018). ${ }^{1}$ SELECT POEMS, / DESIGNED FOR THE / IMPROVEMENT AND AMUSEMENT OF / YOUNG LADIES./ "Tis Goodness best adorns the Female Heart; / "Asks a Respect that must with Years increase / "Lives, when the Roses from the Cheek depart, / "And all the Joys of Adulation cease."/ [rule] / By Miss CARTER, and Others. / [rule] / WATERFORD: / Printed by HUGH and JAMES RAMSEY, Booksellers, on / the QUAY, 1772. Only two copies are known to have survived: these are held at the National Library of Ireland and Cambridge University Library. Further references are from the NLI copy and will be cited in parenthesis. The oblong format at this time is found in children's books, books teaching penmanship, and in hymnals and other music scores. See for example, John Entick, The New Spelling Dictionary, teaching to write and pronounce the English tongue with ease and propriety (Dublin: James Potts, 1770).

${ }^{2}$ The headpiece is similar to that used to decorate the Index of the Ramseys' printing of Samuel Boyse, The New Pantheon (Waterford, 1772). This book, however, includes only 5 printers' ornaments.
} 
indication of the price of the book survives, all of these features suggest that it would have been a relatively expensive book, despite its small size.

In gathering together poems by nine different authors, many of them still living, the collection can be identified as a poetry miscellany, one of more than 5,000 such books published in English in the eighteenth century. ${ }^{3}$ In addition to ten poems by Elizabeth Carter, Select Poems includes two poems by Mary Leapor; two hymns from the Spectator; two short extracts in blank verse from James Thomson; single poems by Alexander Pope, Maria Susanna Cooper, and William Melmoth; and an extract from Amyntor and Theodora (1747) by David Mallet. The authors of two remaining poems have not been identified, although one of these - an 'Ode to Sleep' - was printed in the Pennsylvania Packet (13 July 1772). ${ }^{4}$ The book is currently known to survive in only two copies, contains just twenty poems, and certainly raises more questions than we can answer: who was its compiler, might it have been prompted as a commissioned work, was there a connection with Elizabeth Carter herself or with any of the Bluestockings on either side of the Irish Sea? If, however, as Jennifer Batt has argued, '[e]ach miscellany has its own distinctive story to tell', what glimpse might the Waterford Select Poems give us of a particular moment and time? ${ }^{5}$

\footnotetext{
${ }^{3}$ Michael Suarez notes that the figure is 'considerably higher' than 5,000, and that it includes 'poetical miscellanies, song books, and verse collections of multiple authorship': see Michael Suarez, 'The Production and Consumption of the Eighteenth-Century Poetic Miscellany' in Books and their Readers in EighteenthCentury England: New Essays, ed. by Isabel Rivers (Leicester University Press, 2001), pp. 217-51 (p. 217). For Suarez's influential distinction between the 'miscellany' and the 'anthology' in this period, see pp. $218-9$.

${ }^{4}$ For details of Carter's poems, see note 31 below. The poems by other authors occur in the following sequence: [Mary Leapor] 'Colinetta'; [Alexander Pope] 'Universal Prayer'; [James Thomson] [Untitled] ('Father of Life and Life! Thou Good supreme' and 'Ye mysterious Power!', excerpts from 'Winter' and Sophonisba); two 'Hymns' from the Spectator ('The Lord my Pasture shall prepare' and 'When all thy Mercies, O my God'); 'Ode to Charity', published in Maria Susanna Cooper, Letters between Emilia and Harriet (London, 1762), pp. 116-120 and (Dublin, 1762), pp. 126-130; [unidentified author], 'Hymn' ('Father to thee my Soul looks up'); [Leapor], 'Reflections, by a Gardener's Daughter' printed in Leapor's 1751 Works as “'To Lucinda [August 1746]'; [David Mallet] [Untitled] ('Fountain of light, from whom yon rising Sun'), an excerpt from Amyntor and Theodora (London, 1747), Canto II, 1.100ff; 'To Sappho; a young Lady of thirteen', see [William Melmoth], Letters on several subjects, by the late Sir Thomas Fitzosborne, Bart. (Dublin, 1749), II 33-34; and [unidentified author], 'Ode to Sleep. Written at Twelve o'Clock at Night; occasioned by Reflections on the Corpse of a YOUNG LADY'. The printing of this last poem in the Pennsylvania Packet adds 'lately deceased' to its sub-title and is signed as being by 'S.': Pennsylvania Packet (13 July 1772), 5. Only Carter is identified as author in the Waterford collection.

5 Jennifer Batt, 'Eighteenth-Century Verse Miscellanies', in Literature Compass, 9.6 (2012), 394-405 (p. 397$).$ For the two surviving copies, see note 1 above.
} 
If we consider only the poems by Carter, the Waterford collection is immediately notable in a number of respects: it preceded by five years the first Dublin edition of her poetry; it offered a new, and unique, selection of her poetry; and it identified a specifically young female audience for her work. ${ }^{6}$ It also, as we will see below, advertised Carter's name openly in a way which was untypical both of Bluestocking publications in particular and poetry miscellanies in general. In the mid-eighteenth century, Carter's writings, particularly her translation of the works of Epictetus, had made her famous in both Britain and Ireland. Carter's specific links with Ireland, through networks of Irish friends, would become publicly known in the late 1770s, with poems concerning the Dawson and Vesey families added to editions of her poetry after 1776. Amy Prendergast's monograph study of the literary salon in eighteenth-century Ireland has demonstrated how close the connections were between Bluestockings in Ireland and England, particularly through the friendship of Elizabeth Montagu, Elizabeth Carter, and Elizabeth Vesey, the 'Irish' Bluestocking. ${ }^{7}$ This paper takes a different approach in considering what the Irish editions of Bluestocking writings might tell us about the reception of the Bluestockings, and the ideal of the learned woman more generally, in eighteenth-century Ireland. Before turning to the Select Poems [...] by Miss Carter and Others, however, I will first sketch some contexts for the appearance of the book in Waterford in the early 1770 s.

\footnotetext{
${ }^{6}$ The Irish printings of 'Works' by Hester Chapone (Dublin, 1775) and Hannah More (Cork, 1778) might also be considered new editions, in collecting pieces by these authors not previously printed together. For a discussion of these Irish editions, see below. The definition of 'Bluestocking' adopted in this essay is that of the women writers and correspondents who were connected both through their friendships and through the fame which the group acquired from the 1780s onwards: Elizabeth Montagu, Elizabeth Carter, Elizabeth Vesey, Hester Chapone, Catherine Talbot, and Hannah More. More, for example, would meet Montagu only in 1775 and was not part of the circle in 1772, but later representations of the Bluestockings would depict her as one of the group. The network of friends was never exclusively female, but later depictions of the 'Bluestockings' created a powerful fiction of female-only assembly that continues to dominate our commonplace understandings of the term. See Moyra Haslett, 'Bluestocking Feminism Revisited; The Satirical Figure of the Bluestocking', Women's Writing, 17.3 (2010), 458-77 and 'Becoming Bluestockings: Contextualising Hannah More's "The Bas Bleu"', Journal for Eighteenth-Century Studies, 33.1 (2010), 89-114.

${ }^{7}$ Amy Prendergast, Literary Salons Across Britain and Ireland in the Long Eighteenth Century (Basingstoke: Palgrave Macmillan, 2015).
} 
Waterford in the early 1770 s

Waterford in the early 1770 s was clearly a city with increasing claims to gentility, measurable in its varied social and cultural activities in education, philanthropy, the theatre and publishing. Mrs Anne Butler, who founded a house for twelve distressed widows in 1771 , is just one of many charitable donors whose bequests established relief funds, loan systems and alms houses for the poor. ${ }^{8}$ Waterford's charity and endowed schools were well known in the eighteenth century itself. Charles Smith's published account of the county and city of Waterford gave details of three: one, established by Bishop Nathaniel Foy in 1704; one, for girls, founded in 1740 by Sarah Mason; and a charter school endowed by the Waterford Corporation in Kilotteran in $1744 .{ }^{9}$ The 1826 census of Irish schools would give details of more than 88 schools in the Waterford area. ${ }^{10}$ An interest in advanced education in late eighteenth-century Waterford is also evident in five books reprinted by the Ramseys in Waterford between 1771 and 1775 which advertised themselves as aids to learning Latin, English grammar and classical mythology. ${ }^{11}$ The late 1770 s saw the establishment of a Waterford literary society in which its members experimented with electricity, revered the writings of Laurence Sterne, whose bust presided over their meetings, and composed rival

\footnotetext{
${ }^{8}$ Richard Lahert, 'Some charitable institutions of old Waterford', Decies, 28 (1985), 43-54 and 29 (1985), 2431 .

${ }^{9}$ Charles Smith, The Ancient and Present State of the County and City of Waterford (Dublin, 1746), pp. 189-193 and pp. 377-80. Later, the Catholic merchant Edmund Rice would found the Christian Brothers, opening the order's first school in Waterford in 1802.

${ }^{10}$ See Michael Quane, 'Waterford Schools in the Opening Decades of the Nineteenth Century', in The Journal of the Royal Society for Antiquaries in Ireland, 101.2 (1971), 141-145. Although many of these were founded from the 1790s onwards, Waterford schools clearly outnumbered those listed in Smith's account, not least in terms of non-Anglican provision.

${ }^{11}$ William Hamilton, Hermes Romanus anglicis [...] or, a new collection of Latin words and phrases, for the more ready and exact translating of Garretson's English Exercises into Latin. [...] By W.H. teacher of a private school (1771); Samuel Boyse, The New Pantheon, or, fabulous history of the heathen gods, goddesses, heroes \&c. Explained in a manner entirely new and rendered much more useful than any hitherto published (1772); John Clarke, Erasmi Colloquia selecta: or, the select colloquies of Erasmus. With an English translation, as literal as possible: designed for the use of beginners in the Latin tongue (1773); Cornelius Nepos, Excellentium imperatorum vitae [...] with English notes (1773); Robert Lowth, A Short Introduction to English Grammar, with critical notes (1775). See also Toby Barnard, Brought to Book: Print in Ireland, 1680-1784 (Four Courts Press, 2017), p. 292.
} 
poems in a fashion similar to the famous Batheaston poetry contests held by Lady Miller (1774-1781). ${ }^{12}$ In terms of theatre history, the Aungier Street Dublin company had included Waterford in its southern tour since the 1730s and the theatre established then had allowed a significant local audience to grow. The performance of Harlequin in Waterford (1767), featuring scenery flats with views of Tramore, the Quay of Waterford and Christendom Church, reached out to that audience in very obvious ways. ${ }^{13}$ The publication of play-texts in Waterford, by the Ramseys and by the printer Elizabeth Crawley, also clearly testifies to the popularity of drama at this time. ${ }^{14}$

Waterford women figure in these histories too, and although it is invariably more difficult to recover their experiences, glimpses of their existence, if not always of their lives, survive. In the early 1760s, for example, Susanna Mason's philanthropy was publicly commemorated with a specially commissioned monument by the sculptor John Van Nost which was erected in Waterford's Cathedral. The monument became famous beyond Waterford when its poetic epitaph was published in The Gentleman's Magazine (August 1763), St James’s Magazine (August 1763), Lloyd's Evening Post (September 1763), and in a Manchester-published miscellany of poems, The Polite Miscellany: containing variety of food for the mind (1764) - and doubtless in manuscript commonplace books and other newspapers too. ${ }^{15}$ Van Nost's second sculpture of an Irishwoman also had a Waterford

\footnotetext{
${ }^{12}$ For accounts of this Waterford society, see [Edward Walsh], 'Eccentric Characters, No. 1: Henry Plunket Peters' in The British Magazine (1830), 99-105 (pp. 100-1) and 'Memoir of the late Edward Walsh, M.D.' in The Dublin University Magazine 3 (January 1834), 63-80. Both the ODNB and the DIB follow the second of these accounts in recording that the physician Edward Walsh (1756-1832) founded this literary society in Waterford in the period between his completion of boarding school education in England and the beginning of study at Edinburgh University.

${ }^{13}$ See Michael Brown, The Irish Enlightenment (Harvard University Press, 2016), pp. 234-35. A new, considerably larger, theatre was built in 1784 .

${ }^{14}$ Isaac Bickerstaff, The maid of the mill: a comic opera. As performed at the theatres of Dublin (Waterford: Hugh and James Ramsey, 1768); David Garrick, The Jubilee, in honour of Shakespeare. A musical entertainment at the theatre in Waterford (Waterford: Esther Crawley, 1773); and Joseph Waker, Love in a Cottage, a pastoral (Waterford: Hugh and James Ramsey, 1781).

${ }^{15}$ See The Gentleman's and London Magazine (August 1763), 447; St James's Magazine (August 1773); Lloyd's Evening Post 958 (31 August-2 Sept 1763), 2; and The Polite Miscellany: containing variety of food for the mind; being an elegant collection of moral, humourous, and improving essays (Manchester, 1764), 48.
} 
connection. This was a life-size sculpture of Katharine, Countess of Tyrone, depicted as a sea-nymph, commissioned in 1755 by her husband, Marcus Beresford, first Earl of Tyrone, for the shell grotto which she had created in the gardens of their country estate at Curraghmore House, Portlaw. This sculpture was to inspire a much less decorous poem which also found its way into magazine print:

VAN NOST, I want you to design

A Venus, exqu'sitely fine,

To fill a vacant Niche:

Look on the $\mathrm{O}[\mathrm{rb}] \mathrm{s}$, lovely Pair!

Observe their Attitudes, their Air, Copy no matter which.

Van Nost reply'd, I’ve ready made,

Shoulders and Breast, and Airs of Head,

Which I from them have stole,

With Limbs exactly of a Piece:

O! I'd outrival ancient Greece

Could I ------ but see the Whole. ${ }^{16}$

The satire here appears motivated by an attack on the Tyrones' ostentatious aspiration to high culture, particularly risible, perhaps, because of the provincial setting of the statue. Although the statuary dedicated to Susanna Mason and the Countess of Tyrone inspired very different

\footnotetext{
${ }^{16}$ For an account of the sculpture, see Faulkner's Journal (3 June 1755). The poem, under the title 'To a Famous Statuary', was published in the Whitehall Evening Post (4-6 March, 1756), 3.
} 
kinds of poems, both clearly demonstrate that artistic life in the 'provinces' was not without interest in the metropolitan centres of London and Dublin.

Of particular interest to the 1772 Select Poems are the glimpses of a young girl's life in Waterford in the 1770s which survive in the memoirs of Melesina Chevenix, the granddaughter of the Anglican Bishop of Waterford. She describes attending a fancy-dress ball dressed as the character of the grieving Maria from Laurence Sterne's fiction, for example, and being made to read Charles Rollin's Roman History (1754) when she was seven. By the age of twelve, she noted, her imagination had been infused with the idea of feminine power by reading in her grandfather's library Shakespeare, Sterne, Ovid's Metamophoses, The Arabian Nights, and other fictions and plays. ${ }^{17}$ Slightly lower down the social scale is the figure of Miss Roberts, who painted scenery flats for the theatre in Waterford and is now mentioned only in passing in biographical accounts of her more famous father, the architect John Roberts (1712-1796), and her brother, the landscape-painter Thomas Roberts (1749?1778). ${ }^{18}$ Further down the social scale yet are the gothic novelist Regina Mary Roche (17641845) who was born and died in Waterford, but whose years in the city are shrouded in obscurity, and the Methodist leader Eliza Bennis (1725-1802), who was active in Waterford from 1768 and corresponded with John Wesley about strengthening the church there. ${ }^{19}$ As a final source, we can consider the subscription lists of Waterford-published books which demonstrate the participation of women, often wives and daughters of Waterford merchants, in this conspicuous display of learning and semi-philanthropy. These lists also testify to how 'polite' Waterford extended beyond the Anglican families of the gentry: notable Quaker

\footnotetext{
${ }^{17}$ Melesina Chevenix was born in Waterford in 1768, and the ball described occurred before the death of her grandfather in 1779: see The Remains of the late Mrs Richard Trench: Being Selections from her Journals, Letters, \& other Papers, edited by her son, the Dean of Westminster [Richard Chenevix Trench] (London, 1862), pp. 7-8.

${ }^{18}$ See Anthony Pasquin, An Authentic History of the Professors of Painting, Sculpture, \& Architecture, who have practised in Ireland (London, 1796), p. 8.

${ }^{19}$ See Christian correspondence: being a collection of letters written by the late Rev John Wesley [...] to the late Mrs Eliza Bennis, with her answers (Philadelphia, 1809).
} 
families such as the Grubbs and Penroses feature in the subscription list to the poetry of James Jenkins (Waterford, 1773); Catholic figures and families are prominent in that for Edward Mandeville (Waterford, 1798). ${ }^{20}$

Surviving copies of the Ramseys' newspaper The Waterford Chronicle also confirm this sense of a world of middling and upper-class wealth and aspiration, in which women were actively participating. In 1771, for example, advertisements for dancing and French lessons, harpsichord music, liquorice for medicinal purposes, ladies' fashions, fortnightly assemblies, and a ladies 'memorandum' book, or pocket-journal, amply testify to a local market for such accoutrements of 'polite' female society. Affluent women of the city clearly looked to London as their model of fashionable life. The ladies' memorandum book, for example, includes birthdays of the royal family, favourite new songs sung at Vauxhall, and a 'Table of the Roads between London and Edinburgh' as well as names of the sovereigns of Europe and country dances, rebuses and the dates of saints' days. A stay-maker advertising in the paper emphasises that he has a London correspondent who can give him 'the earliest Notice on the newest Fashions'. ${ }^{21}$ And in December 1771, the Ramseys advertise for sale copies of the depositions of the witnesses in the divorce case of Lord and Lady Grosvenor, the cause célèbre of gossip in London at this time..$^{22}$

Clearly, then, many women of gentry and merchant backgrounds in the 1770 s could lay claim to being 'cultured' in the sense of reading, writing, frequenting the theatre, buying

\footnotetext{
${ }^{20}$ The subscription list for James Jenkins, Juvenile Poems on Several Occasions (Waterford: Esther Crawley, 1773 ) includes the names of seventy female subscribers (of almost three hundred subscribers in total) and that for Edward Mandeville, Miscellaneous Poems (Waterford: John Veacock, 1798) names forty-two women. The list for Mandeville's Poems also includes both Anglican and Catholic bishops of Waterford (Richard Marlay and William Egan, respectively, with Egan subscribing for four copies). See also Toby Barnard's discussion of the 1752 edition of Charlotte McCarthy's novel, The Fair Moralist. Although no publisher is named in this edition, the subscription list suggests a Waterford printer. One fifth of the subscribers were female: see Barnard, Brought to Book, p. 338 and Rolf Loeber and Magda Loeber in collaboration with Anne M. Burnham, A Guide to Irish Fiction, 1650-1900 (Four Courts Press, 2005), pp. 1400-1.

${ }^{21}$ For all of these advertisements, see the January 1771 issues of The Waterford Chronicle.

${ }^{22}$ In this action, the charge of criminal conversation had been brought against the Duke of Cumberland, brother of George III. See The Waterford Chronicle (31 December 1771).
} 
fine fashion, acquiring accomplishments as an index of refinement, and engaging in philanthropic schemes. In an introductory address the editor of The Golden Cabinet (Waterford, 1765) writes of how his original intention had been to publish guidelines on drawing and painting in watercolours for the ladies, but that the book expanded into a more general compendium: 'The many (and interesting) particulars now added thereto, will certainly be acceptable to every reader, that has the least veneration for Arts and Sciences, the support, the life, the glory of a free people, and trading nation' ${ }^{23}$ Confident articulations of this kind suggest that the early 1770 s was an auspicious moment in which an Irish provincial publishing firm might publish a new book of poetry, specifically for an audience of 'young ladies'. And, although recent histories of print have emphasised the relatively small number of books published in provincial towns in Ireland in this period, it remains important to consider the possible significance and implications of even one title, especially if it is a unusual book, such as Select Poems, designed for the improvement and amusement of young ladies. ${ }^{24}$ Given the prominence assigned to Elizabeth Carter, the following section outlines Carter's considerable renown in Britain and Ireland in the late eighteenth century, before turning to the Waterford miscellany which advertised her name so boldly on its title-page.

\section{Select Poems [...] by Miss Carter and others}

As the title-page indicated, a number of these poems were by Elizabeth Carter, who was famous as a poet and translator, though, by the early 1770 s, she was not yet famous as one of

\footnotetext{
${ }^{23}$ The Golden Cabinet: or, the World's Jewel. Being a Shilling profitably Exchang'd, for a Valuable Instructer, in such Branches of Useful Knowledge, that nearly concern all Kinds of People, from the Peer to the Peasant, and renders the Whole a Complete School of Arts, that leads to Profit and Delight (Waterford: Thomas Richey, 1765), pp. iv-v. For more on the self-confidence of Waterford city in the eighteenth century, see Walton, 'Classicism and Civility' Irish Arts Review, 21.1 (Spring 2004), 102-107, and William Laffan and Brendan Rooney, Thomas Roberts: Landscape and Patronage in eighteenth-century Ireland (Churchill House Press, 2009), p. 15.

${ }^{24}$ See Colm Lennon, 'The Print Trade, 1700-1800' in The Oxford History of the Irish Book, Volume III: The Irish Book in English 1550-1800, ed. by Raymond Gillespie and Andrew Hadfield (Oxford University Press, 2006), pp. 74-87 (p. 77) and Barnard, Brought to Book, pp. 295, 368.
} 
the Bluestockings. Poems which she had published in the Gentleman's Magazine in the 1730s, and translations of works from Italian and French had won her early fame in literary circles in London. In the anonymously published pamphlet, Woman's Superior Excellence over Man (1740), for example, she had been cited as a modern example of 'towering superiority of [...] genius and judgment'; in the weekly periodical, The World (1755), she was imagined becoming warden of an Oxford college. ${ }^{25}$ Her highly regarded translation of Epictetus (1758) confirmed her status as the most renowned learned woman in England even more decisively. Thereafter, Sarah Fielding praised her in print as 'not only a Credit to her Sex, but an Honour to her Country' (1762); she was nominated as poet laureate in a whimsical essay entitled 'Humorous Proposal for a Female Administration' (1766); and was featured in four monthly issues of The Ladies Magazine in $1772 .{ }^{26}$ These examples are typical of the many compliments paid to Carter in print, in laudatory poems addressed to or about her, fictional representations, positive reviews of her translations, and honourable mentions. $^{27}$

Carter was clearly known in Ireland too. On its first publication, the London printers of the Works of Epictetus (1758) had had to prepare additional copies to cope with the demand which is amply evidenced in its list of 1,031 subscribers, nine of whom were Irish archbishops and bishops: the Primate, the Archbishop of Tuam, and the Bishops of Clogher, Derry, Ferns, Kildare, Killala, Limerick (2 copies), and Waterford. One year after its London

\footnotetext{
${ }^{25}$ Woman's Superior Excellence over Man [...] by Sophia, a Person of Quality, Author of Woman not inferior to Man (London, 1740), p. 47. The comment referred to her simply as 'Eliza', but the alias had been openly revealed to be Carter in early poetic exchanges in The Gentleman's Magazine. [Edward Moore], The World, by Adam Fitz-Adam, no 131 (Thursday, 3 July 1755), 159-65.

${ }^{26}$ Sarah Fielding, Xenophon's Memoirs of Socrates (Bath, 1762), p. 317; 'Jacobina Henriques', 'Humorous Proposal for a Female Administration', in the Annual Register, 9 (1766), 209-212 (p. 211); The Ladies Magazine, 3 (May 1772), 220; 3 (July 1772), 322; 3 (August 1771), 379; 3 (September 1772), 410. ${ }^{27}$ See for example, John Duncombe's The Feminiad (1754, 1757); Sarah Fielding and Jane Collier's anonymously published novel, The Cry (1754); Edward Young's poem Resignation (1761); and Clara Reeve's poem, 'To my Friend Mrs --- On her holding an Argument in Favour of the Natural Equality of both the Sexes' (1769). Carter was also thought to be depicted in a number of Richardson's heroines, including Anna Howe (in Clarissa) and Mrs Shirley (in Sir Charles Grandison).
} 
publication, a Dublin octavo edition of the Works of Epictetus (1759) was organised, with

135 subscribers, headed by the Duke of Bedford, then Lord Lieutenant of Ireland, and his wife, and including the Lord Chancellor (Lord Bowes) and the Speaker of the House of Commons (John Ponsonby). The Primate subscribed to the Dublin, as he had done to the London, edition, and was joined by the Bishops of Kilmore and of Meath. Although a posthumously published letter suggests Carter's disappointment with the lack of support for Epictetus shown by 'the Irish bishops', it is clear from the subscription list to the Dublin edition that her translation was known and supported in Ireland, even if only half of the Irish Anglican bishopric helped to finance its publication. ${ }^{28}$ Carter's most famous poem, the 'Ode to Wisdom', was widely known through its inclusion in Clarissa (1748-49) by Samuel Richardson. The Dublin edition of the novel, like its London counterpart, had included a foldout page of engraved musical notation, representing Clarissa's setting of the poem's last three stanzas. ${ }^{29}$ Many of the texts which celebrated Carter had had Dublin editions, and some texts exclusive only to Dublin referred to Carter also. ${ }^{30}$ In this context, it is not surprising that the Waterford publication advertised Carter's name so openly on its title-page: the first nine of the twenty poems in the collection, and just over half of its pages, are by Carter. ${ }^{31}$

\footnotetext{
${ }^{28}$ See Montagu Pennington, Memoirs of the Life of Mrs Elizabeth Carter with A New Edition of her Poems (London, 1807), p. 142. In the eighteenth century, there were four Church of Ireland archbishops and eighteen bishops, so eleven subscribers out of a possible total of twenty-two may well have represented poor support from Carter's perspective. The 'Irish bishopric' was joined in her complaint with 'the universities'. ${ }^{29}$ Samuel Richardson, Clarissa. Or, the history of a young lady, 7 vols (Dublin: Faulkner, 1748-49), II (1748), between pp. 50 and 51. Although Richardson included the 'Ode to Wisdom' as a poem written by a lady, Carter's identity became quickly known: Poems by Eminent Ladies (London 1755; Dublin 1757), for example, included the poem as one of their Carter selections, and the poem was also included in Carter's Poems on Several Occasions (London, 1762).

${ }^{30}$ All but one of the texts named above, for example, had Irish editions, the one exception being the pamphlet by 'Sophia'. For an example of an Irish original publication, see A Colloquial Essay on the Liberal Education, and Other Interesting Subjects. Published by Order of the Milesian Club (Dublin, 1764), pp. 30-31.

${ }^{31}$ Ten poems by Carter are reprinted as nine poems in the Waterford collection and follow this sequence: [Untitled here, but printed in Carter's poetry collections as 'In Diem Natalem'] ('Thou Power supreme, by whose command I live'); 'On a Watch. To Miss _ _ __-' ('Unlike the Triflers, whose contracted view'); [Untitled], ('While Night in solemn Shade invests the pole') - this poem immediately follows the final line of the preceding one without an indication that this is a new poem; 'Written at Midnight, in a Thunder Storm. To Miss _ _ __' ('Let coward Guilt, with pallid Fear'); 'On a Watch. To --.--.-' ('While this gay Toy attracts thy Sight'); 'To Miss ——__' ('While soft thro' Water, Earth, and Air'); 'To Miss —— — , From her guardian Angel' ('From Climes where one eternal Spring'); 'To - - - - ' ('The midnight Moon serenely smiles'); 'Ode to Melancholy'; and 'Ode to Wisdom'.
} 
The title-page identification of Carter is repeated on the first page of the poems themselves (p. 3) and the last of the poems by her is her most famous poem, the 'Ode to Wisdom'. None of the authors of the poems which follow are identified, although the first of these, Mary Leapor's 'Colinetta', was also frequently anthologised and was recognisably not by Carter, with its account of the death of a rural labouring-class woman. Readers thus, we can presume, would have recognised that all of the poems which follow are by the 'others' of the collection's title: Pope's 'Universal Prayer', for example, was a particularly famous poem which was frequently anthologised and printed under Pope's own name. Similarly, the collection's epigraph is taken from a poem by George Keate, a writer little known today but whose verse was often reprinted in the eighteenth century. ${ }^{32}$ As a whole, the Waterford volume collects together poems frequently selected for reprinting with those which appear never to have been chosen for other collections. Using the on-line database, the Digital Miscellanies Index, an approximate sense of the frequency of reprinting of popular poems can be at least partially mapped. ${ }^{33}$ Unsurprisingly, Carter's 'Ode to Wisdom', Addison's poetic version of Psalm 23, and Pope's 'Universal Prayer' recur in many miscellanies. But four of Carter's poems, one of the poems by Leapor, and the 'Ode to Charity' which had been included in a novel by Maria Susanna Cooper appear to have been rarely, if ever, reprinted in miscellanies prior to the Waterford collection. While such searches are not exact, they are at least indicative and certainly prove that, as a collection, the Waterford volume was a unique miscellany, at a time when many miscellanies drew upon familiar, frequently reprinted material. $^{34}$

\footnotetext{
${ }^{32}$ The epigraph consists of a four-line excerpt from 'The Ruins of Netley Abbey' by George Keate (London, 1764), p. 10, though the compiler's source could have been the printing of an extract, including these lines in particular, in The Gentleman's Magazine (August 1765), 489-90 (p. 490). See illustration 1.

${ }^{33}$ The Digital Miscellanies Index is an on-line searchable catalogue of 1,750 poetic miscellanies published between 1557 and 1800: see http://dmi.bodleian.ox.ac.uk/.

${ }^{34}$ For miscellanies' borrowing from each other, see Suarez, p. 225. The following poems in the Waterford volume showed no printings in miscellanies prior to 1772: Carter's poems ['In Diem Natalem']; the two poems titled 'On a Watch'; and 'To Miss ---, From her guardian Angel'; the poem printed in Cooper's novel, 'Ode to Charity'; the unidentified 'Hymn' ('Father to thee my Soul looks up'); Leapor's 'Reflections, by a Gardener's
} 
The selection is obviously devised for a young audience: there is the clear evidence of the collection's title, with its open reference to 'young ladies'. The first poem in the collection, Carter's poem on her birthday, 'In Diem Natalem', is printed with a new subheading which makes her own comparatively young age when writing the poem pointedly obvious: 'Written by Miss Carter, in her Eighteenth Year'. Another of Carter's poems is spoken by the 'guardian angel' of a dear friend, who claims that she has watched over her from her infancy (pp. 24-8). William Melmoth's poem is addressed to a 'young lady of thirteen' (pp. 84-7). Leapor's 'Colinetta' includes lines in which the speaker recalls infant days, gathering 'King-cups' (p. 50). One of the hymns includes recollections of babyhood (p. 64). And the collection ends with two pages of advertisements of books for children (see image 5). ${ }^{35}$ Poems originally published with Latin titles or epigraphs have those elements silently omitted. ${ }^{36}$ And significant changes to the texts of several of the poems also add to the sense that a relatively young audience is envisaged for the collection. For example, one stanza of the 'Ode to Charity' is emended so that a learned reference to the ancient Roman writer Varro is omitted:

But ye, who would be truly great,

From a Varro's gen'rous Mind

Learn to despise the Forms of State,

Like him, to bless Mankind. (Cooper, p. 129)

Daughter'; and the unidentified 'Ode to Sleep'. However, Leapor's 'Reflections' had first been published in The London Magazine (1747) and the 'Ode to Sleep' was published in the same year as the Waterford collection in The Philadelphia Packet.

35 These include popular children's stories, devotional works, didactic works and a number of spelling books which were printed in London and imported for the bookselling part of their business. Books in this list printed by Newbery were also being advertised for sale in Cork in 1771: see Barnard, Brought to Book, p. 282.

${ }^{36}$ The Latin epigraphs for 'In Diem Natalem' and 'Ode to Melancholy' are omitted, as is the Latin title of the first of these, and the collection ends with 'The End', rather than the 'Finis' which concludes all other Ramsey publications. 
But ye, who would be truly great,

From a true gen'rous Mind,

Learn to despise the Forms of State

Be thought to bless Mankind. (Select Poems, p. 72)

And, in comparing 'To Sappho' with two other printed versions, the Waterford miscellany can be seen to introduce the following substantive variant: 'Those little conquests of her sex to scorn' becomes 'The little conquests of her pen to scorn', a change which removes the suggestion of coquetry and flirtation, probably as inappropriate for a young audience. ${ }^{37}$

In addition, a reading of the poems demonstrates a sustained focus upon common themes across the selections, and the most significant of these address young readers, young female readers in particular. Youth, ageing, and morality are constantly imbricated through the poems' emphasis upon the importance of virtuous, religious behaviour. In Leapor's 'Colinetta' the speaker is on the point of death and uses her final words to reflect upon a life which, though short-lived, was virtuous. The final poem, the 'Ode to Sleep', consists of reflections upon the corpse of a young woman, while the opening poem, Carter's 'In Diem Natalem', uses the occasion of her birthday to reflect upon her own mortality. Carter's two poems which take a watch as their theme also obviously address the passing of time and urge their readers to live a devout life. And while this might make the collection sound to modern ears a rather forbidding one, the dominant mood instead is one of serenity, in which a spiritual life allows one to meet death with calm equanimity.

\footnotetext{
37 The first of these lines is as printed in both Melmoth, II 33-34 and The New Foundling Hospital of Wit ... Part the fourth (London, 1771). See also the following changes: collation of Leapor's poem 'To Lucinda' against its closest printed version suggests that its sub-title was changed from 'Inscribed to a Lady' (1747) to 'Inscribed to a young Lady' (1772): see London Magazine, 16 (January 1747), 45. This 1772 printing of 'To Lucinda' was compared with the texts printed in The London Magazine (1747) and in Leapor's Poems upon Several Occasions (1751), pp. 58-61. Nine substantive variants were found: in five of these the Waterford text agrees with 1747; in only one of these does it agree with 1751; and it is unique in three instances.
} 
The poems are thus predominantly, unsurprisingly didactic. They urge their readers to use their time wisely and not to court the good opinion of the vain and foolish. One of the poems 'On a Watch' ends with the injunction: '[To] seek from Beauties form'd on Virtue's Rules, / Th'Applause of Angels, not the Gaze of Fools' (p. 15). Many of the poems encourage girls to employ reason and to keep passion under check. In 'Written at Midnight in a Thunder Storm', readers are reminded that God is ever-present in varying situations, so that the storm should hold no terrors. 'Reason', the poem argues, will teach the ability 'to scorn those Fears / That vulgar Minds molest' (p. 17). Much of the poetic advice is conventional: that female youth should scorn the superficial opinion of those who value their appearance, rather than their qualities, is familiar from the poetry of Pope and countless others. But Carter's emphasis is upon the innate intelligence of the women she addresses:

While sighing Crouds of rival Youths

Their idle Homage pay,

Reflect, how soon the transient Reign

Of Beauty must decay. [...]

Amidst the frolic Sports of Youth,

Some lasting Charm engage,

To gild the solitary Gloom

Of unadmir'd Old Age. [...]

To Time's inexorable Pow'r

Has Heav'n's Decree consign'd, All but the undecaying Bloom 
Of fair, immortal Mind. [...]

Tho' Charms thus modest and retir'd

Attract no Coxcomb's Sight, Applauding Angels own their Worth, And view them with Delight.

('To Miss —. From her guardian Angel', pp. 26-8)

And the confidence of this poem in dismissing coxcombs so easily is grounded in the collection as a whole, with its repeated celebrations of intellectualism and female camaraderie.

This is certainly a collection which takes young women's pretensions to learning seriously. While the impressive classicism of Carter herself may be beyond the reach of this young audience, the ideals of rational thought and female friendship are held in view throughout. Almost all of the poems speak to women both within and beyond their texts and often this address is made explicit in the poems' titles: six of Carter's poems are addressed to female friends; Melmoth's 'To Sappho' has as its sub-title 'a young Lady of thirteen'; and Leapor's poem 'Reflections' takes a new sub-title here: 'Inscribed to a young Lady'. The anonymous addressees of Carter's poems would later be identified in Pennington's 1807 edition of her work but female readers far from Deal, or London, could evidently witness and even participate within the virtual female community which such verse epistles created.

The compilation as a whole neatly balances 'improvement' with the 'amusement' which is also promised on its title-page. 'Religious verse' might aptly apply to all the poems in the collection, from those poems which take the form of hymns or prayers to God, often asking for his guidance, to the prominence of injunctions to female moral virtue throughout. 
All of the Carter poems end either with the applause of angels (as in the poem above) or with an exalted affirmation of Christian eternity. And the dominant mood throughout the selection of Carter's poems is thus one of sublimity rather than resignation. See, for example, the following extract from the early poem by Carter on her birthday:

Thy Skill my elemental Clay refin'd,

The vagrant Particles in Order join'd,

With perfect Symmetry composed the Whole,

And stamp'd thy sacred Image on my Soul!

A Soul, susceptible of endless Joy,

Whose Frame, nor Force, nor Time, can e'er destroy;

Which shall survive when Nature claims my Breath,

And bid defiance to the Darts of Death;

To realms of bliss with active Freedom soar,

And live, when Earth, and Skies shall be no more! (p. 4)

The collection's attention to mortality also resonates with a late century taste for the gothic: Carter's two odes share the imagery and mood of night-pieces and graveyard settings which had grown in popularity across the century; the anonymous 'Ode to Sleep' is given a frisson of troubled excitement with its subtitle - 'Written at Twelve o'Clock at Night; occasioned by Reflections on the Corpse of a YOUNG LADY'.

The collection is not without humour also. Mary Leapor's 'Colinetta' neatly balances comedy and pathos, as, for example, when Colinetta bequeaths her lowly worldly possessions to her various friends: 
When I am gone, I leave to Sister Sue,

My Gown of Jersey and my Aprons blue;

My studded Sheep-hook Phillida may take,

Likewise my Hay-fork and my Hazel Rake;

My hoarded Apples and my Winter Pears

Be thine, O Lydia! to reward thy cares. (p. 53)

Although the selection of Carter's poetry is not always flattering to her as a poet - poems which demonstrate Carter's dazzling intellectualism, such as 'While clear the Night', with its detailed knowledge of astronomy, for example, is not included - Carter's most famous odes, the 'Ode to Melancholy' and 'Ode to Wisdom', do demonstrate her poetic skill and intellectualism. And the sublimity of Carter's style throughout lifts the poetry beyond quietistic morality and gives a strong sense of how intellect can ensure immortality.

Although we do not know who the compiler of the miscellany was, the evidence of the book itself, particularly its format and lay-out, suggests someone who wished to create a book of some quality. But while there are relatively few errors in the texts, one serious mistake - in which two poems by Carter are conflated into one - would appear to rule out the involvement of Carter herself or of any of her closest friends (see image 6) ${ }^{38}$ However, the

\footnotetext{
${ }^{38}$ The Waterford collection mistakenly prints as one poem Carter's 'On a Watch. To Miss -------' ('Unlike the Triflers whose contracted View') and 'While Night in solemn Shade invests the pole'. In earlier London printings of the second of these poems, no title is given and it follows immediately after the preceding one, though separated from it by a printers' ornament: compare Carter, Poems on Several Occasions (London, 1762 and London, 1766, $2^{\text {nd }}$ edn), p. 31 with Select Poems (Waterford, 1772), p. 11. Possibly for the removal of any doubt, the $3^{\text {rd }}$ London edition and the $4^{\text {th }}$ Dublin edition both print 'While Night in solemn Shade invests the pole' on a new page: see Carter, Poems on Several Occasions (London, 1776; Dublin, 1777), p. 32. Other significant errors include: the omission of two lines from 'On a Watch. To Miss ------' ' 'Unlike the Triflers whose contracted View') and the printing of 'Intellectual Life' instead of 'Intellectual Light' in the 'Ode to Wisdom': see Carter, Poems (1762), p. 31 11.39-40 and Select Poems (1772), pp. 11-12; and Carter, Poems (1762), p. 89 and Select Poems (1772), p. 46. Collation of the poems suggests that the first London edition (1762) was the copy-text for Waterford 1772.
} 
collection remains as a significant publication by one of the Bluestockings, and it is to this wider context that I will now turn.

\section{Irish editions of the Bluestockings}

Miscellanies in the eighteenth century frequently printed poems, or extracts from longer poetic works, without attribution. ${ }^{39}$ That Carter alone should be so identified is an additional aspect of this book's curiosity. While the eighteenth century witnessed a steady increase in miscellanies in general, and miscellanies for female audiences in particular, no other title in the century profiled the work of a female author above the collection's other contributors. ${ }^{40}$ Given the fame of Carter, a fame which reached well beyond England (the Pennsylvania Gazette named her as a lady of 'eminence and Merit' in 1775, for example), the marketing of this miscellany as containing poems 'by Miss Carter and others' drew upon the cachet of Carter's name and what it represented: for, almost uniquely, Carter could figure as an index not just of respectable female learning, but also of a kind to which aspirant middling class daughters, in Ireland as elsewhere, could aspire. ${ }^{41}$

However, the specific ways in which Carter was bound to Ireland were known only to her friends and acquaintances at this point. In letters to Vesey, Carter wrote of what she called her 'great partiality for Ireland' (6 June 1773). The following two examples confirm this 'partiality': 'I seem, more than any English woman ever did, to belong to the whole

\footnotetext{
${ }^{39}$ Abigail Williams “'A Just and Graceful Elocution”: Miscellanies and Sociable Reading' in EighteenthCentury Life, 41.1 (January 2017), 179-196 (pp. 189-90).

${ }^{40}$ Although it was common for a named poet's volume to include contributions by others (see, for example, Mary Barber's Poems on Several Occasions, 1735), it was rare for a work which announced itself as a miscellany to name only one author on its title-page and unprecedented for that author to be a woman. See, for example, Poems written occasionally by the late John Winstanley [...] interspers'd with many others, by several ingenious hands, 2 vols (Dublin, 1742; 1751); and A Collection of Poems, Principally consisting of the most celebrated pieces of Sir Charles Hanbury Williams, Knight of the Bath (London, 1763).

${ }^{41}$ The Pennsylvania Gazette (16 August 1775), 5. The English historian Catharine Macaulay is also named alongside Carter in this piece.
} 
kingdom of Ireland: I find myself growing more and more Irish every winter of my life' (7

February 1772); and, in a passage alluding to Swift's A Modest Proposal:

Indeed you pay me much too high a compliment in accusing me of the defection of your country women. I scarce ever met with an Irish woman in my life, who did not in a very kindly manner take root and flourish in the soil of England. We are much obliged to you all for this partiality, for you have among you imported more sense and virtue than I fear we are likely to repay you, by all the hungry people whom we send to eat you up from thence. $(21 \text { November } 1771)^{42}$

By 1776, those Irish connections were becoming more obvious. Among the new poems added to the third edition of Carter's poetry (London, 1776; reprinted in Dublin, 1777 as a 'fourth' edition) were poems openly addressed to Elizabeth Vesey and to members of the Anglo-Irish gentry family, the Dawsons, in addition to a memorial inscription to Lady Anne Dawson. This latter text - and the friendship it celebrated - had been publicised more widely than the poetry collection itself when the Hibernian Journal (19 August 1774) noted the arrival in Dublin of the monument to Lady Dawson, on its way to Dawson Grove, Co. Monaghan. ${ }^{43}$ At the moment of the publication of Select Poems, however, the connections between Carter and such Irish friends as Elizabeth Vesey, Lady Dartrey, and the late Lady Anne Dawson, were not widely known. And Carter's identification as one of the

\footnotetext{
${ }^{42}$ A Series of Letters Between Mrs Elizabeth Carter and Miss Catherine Talbot [...] to which are added, Letters from Mrs Elizabeth Carter to Mrs Vesey, Between the Years 1763 and 1787, 4 vols (London, 1809), IV, 80; IV, 45; and IV, 42-3.

${ }^{43}$ Poems on Several Occasions (London, 1776 and Dublin, 1777): 'To Mrs Vesey. 1766'; 'To the Hon. Thomas Dawson, Ætat. 2, 1773'; 'To the Right Hon. LADY DARTREY'; and 'Inscription on Lady Ann Dawson's Monument'. Carter's close friendship with Philadelphia Lady Dartrey (from 1785, Viscountess Cremorne) was later commemorated in a poem written to her when Carter was 77, printed in Pennington's posthumous Memoirs (1807) of her life, a work which Pennington also dedicated to Viscountess Cremorne.
} 
Bluestockings would come later too, as the accumulation of reports of and references to the Bluestocking circle would similarly occur only from the late 1770 s onwards.

Might the printing of Select Poems have been supported by Carter herself or by friends in Ireland? Elizabeth Montagu suspected that Elizabeth Vesey was involved in the Dublin edition of her Essay on the Writings and Genius of Shakespeare (1769). ${ }^{44}$ And in the following suggestive letter, sent from Carter in Deal to Vesey in Lucan in 1772, there is a hint of a particular favour which might plausibly be involvement in a printing enterprise:

You have laid me under a restraint, which I feel the more difficult for the very reason that you assign for it, as its being a mark of your affection is the circumstance that would most naturally tempt me to talk of it; however, I promise to be very prudent, and, like Queen Midas, I will whisper the secret only to the reeds, and I think they can scarcely blab it beyond the county of Kent, where as nobody knows you, nobody knows or cares how little or how much you love $\mathrm{me}^{45}$

While it is tempting to speculate that Carter might be referring to the Waterford volume, possibly published with the help of Vesey, this is not proven. The only Waterford connections I have been able to establish for Carter are the following: Carter had been very close to both wives of Thomas Dawson, Baron Dartrey (later Viscount Cremorne), who owned an estate near Dungarvan, Co. Waterford; the Bishop of Waterford, Richard Chenevix, had been among nine Irish bishops who subscribed to Carter's London edition of Epictetus;

\footnotetext{
${ }^{44}$ For Montagu's comments on the Dublin edition of her Essay, see Prendergast, p. 104.

${ }^{45}$ Carter, A Series of Letters (1809), IV, $65-6$ (June 1772).
} 
and the Waterford-born artist, Thomas Roberts, had painted for the Vesey, Bingham and Dawson families.

Thus no concrete evidence exists for a link between Carter, or her Irish friends, and the printing of the Waterford book. Indeed, other than Montagu's knowledge of the Dublin edition of her Essay, Irish reprints of Bluestocking works, including the Waterford selection of Carter's poetry, do not appear to have been noticed by the Bluestockings in England at all. In addition, Carter herself had been reluctant to sanction unauthorised printings of her work: she had challenged Samuel Richardson over the publication of the 'Ode to Wisdom' in Clarissa, and she also appears to have withheld permission for Dodsley to publish further poems by her in his Collection of Poems by Several Hands (6 vols, 1748-58), the best-selling miscellany of the eighteenth century. ${ }^{46}$ Given this control over her work, and the absence of references to the Waterford collection in surviving correspondence of Carter and her Bluestocking friends, then, it seems likely that the Waterford printing did not have the support of Carter.

Between 1770 and 1772, Carter had been busy with the editing and publishing of works by her late friend Catherine Talbot: Reflections on the Seven Days of the Week (1770) and Essays on various subjects (1772). Work on the first of these had begun shortly after Talbot's death in 1770 , and the editions, unlike printings of Carter's own writings, were organised at Carter's own expense. Both works were quickly reprinted in Dublin, in editions which openly identified Catherine Talbot as the author and which subtly adapted the 'Advertisement' of the first London editions for a more general readership, beyond the circles of influence and acquaintanceship which might be said to characterise a significant number of the readers of the London editions. The original London 'Advertisement' for the Reflections primarily addressed those who had known Talbot personally:

\footnotetext{
${ }^{46}$ See Bigold, pp. 173-75, 181-82, 188.
} 
It is hoped, that the good Sense, and exalted Piety of these Reflections, may render them of some use to the World in general: And Those who had the Happiness of a personal Acquaintance with the Author, will be pleased to have an Opportunity of profiting by her Thoughts, now they are no longer permitted to enjoy the Blessing of her Example. ${ }^{47}$

Thomas Ewing's Dublin edition adapts this wording and explicitly names Talbot as the author. Both decisions have the effect of reaching out more self-consciously to that 'World in general' which had been briefly invoked in the London editions:

It is hoped, that the good Sense, and exalted Piety of these Reflections, may render them of some Use to the World in general: They were written by MISS C. TALBOT,* who, to the finest Imagination, and the most elegant Accomplishments of her Sex, added the gentlest Manners, and a Disposition thoroughly benevolent and Devout.

Those in particular, who had the Happiness of a personal Acquaintance with the Author, will be pleased to have an Opportunity of profiting by her Thoughts, now they are now longer permitted to enjoy the Blessing of her Example.

*For a particular Account of this Lady, see the Life of Archbishop Secker, prefixed to his Works. ${ }^{48}$

\footnotetext{
${ }^{47}$ Reflections on the Seven Days of the Week (London: John and Francis Rivington, 1770). This Advertisement appears in all but one of the London editions of the Reflections (' $4^{\text {th }}$ edition', 1770?). Of the 19 London editions and re-issues of Talbot's writings recorded on ESTC, only two openly identified Talbot as the author (1780 and 1795), though a number refer to her as the author of the 'Essays'. All of the London printings of Talbot were by the Rivingtons.

${ }^{48}$ Reflections on the Seven Days of the Week by Mrs Talbot. The eighth edition (Dublin: Thomas Ewing, 1772). Ewing's edition of Talbot's Works (1773) also included this advertisement, as did the later Cork edition of Reflections (Cork, 1796). J. Milliken's rival Dublin edition of Talbot's works (2 vols, consisting of her 'Essays'

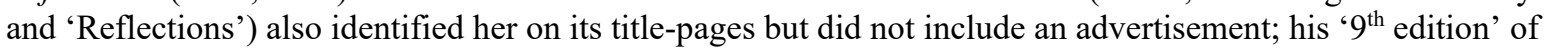


The footnoting here points us to the source for the new wording of the first paragraph, as the statement on Talbot's imagination, accomplishments, manners and disposition is taken verbatim from the biographical notice of Secker by Beilby Porteus, published in London in $1770 .^{49}$

On the basis of such comparison, we can see that the Irish reprints of Talbot's works are almost certainly unauthorised: Carter is unlikely to have agreed to the open publishing of Talbot's name on the title-page or in the advertisement. And despite the relatively quick reprintings of Talbot's works in Dublin, we know that Elizabeth Carter asked Lady Dartrey and then Penelope Dunbar to take a copy of the (London-printed) Essays back to Ireland as a gift to Elizabeth Vesey. ${ }^{50}$ Although the sale catalogue of Vesey's library demonstrates that she owned a substantial number of Dublin-printed books, all of the Bluestocking publications recorded there are London editions. ${ }^{51}$ The preference for London editions is also clearly seen in the earlier case of Carter's Epictetus. As noted above, nine Church of Ireland bishops subscribed to the London edition; only three subscribed to the Dublin edition (including the Archbishop of Armagh, who subscribed to both). And although Patrick Delany subscribed to more copies of the Dublin than of the London edition, his wife Mary - friend of many of the Bluestockings herself - subscribed only to the London edition. ${ }^{52}$ These points, taken with the error in printing two Carter poems as one, all suggest that neither Carter nor her Irish friends were involved in the Waterford collection.

\footnotetext{
the Reflections (Dublin, 1775?) and the ' $10^{\text {th }}$ edition' published in Drogheda (1784) also identified Talbot as the author and reproduced the London advertisement.

${ }^{49}$ Sermons on several subjects, by Thomas Secker, LL.D, Late Lord Archbishop of Canterbury [...] To which is prefixed a review of his Grace's life and character, 4 vols (London: J and F Rivington, 1770), I, xcv-xcvi. See also The Works of Thomas Secker, LL.D, Late Lord Archbishop of Canterbury [...] To which is prefixed a review of his Grace's life and character, 6 vols (Dublin: J. Williams, 1775), I, lx.

${ }^{50}$ Carter, A Series of Letters (1809), IV, 57 (17 April 1772) and IV, 66 (12 June 1772).

${ }^{51}$ The Library of Mrs Elizabeth Vesey 1715-1791 (William H. Robinson, 1926). No book by Catherine Talbot is included.

52 Patrick Delany subscribed for three copies of the London, and six copies of the Dublin edition.
} 
Nevertheless, the Waterford printing of Carter's poems in 1772 continues to have an important role to play in the wider history of interest in the Bluestockings in Ireland, with significant reprinting of key works both in Dublin and in the provinces. Eight editions of works by Hester Chapone (1727-1801), for example, were published in Dublin between 1773 and $1786 .{ }^{53}$ Talbot's works were reprinted in Drogheda (1784) and Cork (1796) in addition to the Dublin editions named above. And Hannah More's plays, poetry, polemical and didactic works and, later, her cheap repository tracts, were all reprinted in multiple editions in Ireland, with a Belfast edition of her tragedy Percy (1778) and two Cork printings of her Works (1778, 1789), which, like the Waterford miscellany, offered a collection of her work that differs from other printings. ${ }^{54}$ Although we cannot simply infer an Irish audience from the existence of Irish reprints, a number of publications clearly point to local emphases and interests. The publication of the dissenting poet Aikin in Belfast, where Dissenters outnumbered other denominations; the Cork edition of the Bluestocking-related novel, Histories of some of the Penitents in the Magdalen House which coincided with the opening of a Magdalen institution there; and the Newry edition of the religious contemplations of Elizabeth Rowe, compiled by Isaac Watts, Devout Exercises of the Heart: all of these suggest that Irish provincial printers were selecting works which would appeal to readers in these particular towns and cities. ${ }^{55}$ And in addition to the Irish reprints, many booksellers in Ireland

\footnotetext{
${ }^{53}$ Dublin editions of Chapone's Letters on the improvement of the mind were published in 1773, 1774 and 1777; Miscellanies in prose and verse in 1775; A Letter to a New-Married Lady in 1777; and the combined Works in 1775 (twice) and 1786. Miscellanies was dedicated to Elizabeth Carter.

${ }^{54}$ Montagu's Essay also had a second Dublin edition (Dublin, 1778) and there were a number of Dublin reprints of Lyttleton's Dialogues of the Dead, to which Montagu had contributed $(1760,1765)$. At least 72 reprints of More's cheap repository tracts were sold in Dublin, the vast majority printed by William Watson, the publisher of Carter's Dublin edition of poetry (1778).

${ }^{55}$ Anna Laetitia Aikin, Poems (Belfast, 1774). The fictional Histories was read in manuscript by Carter, Montagu and Talbot; was first published in London in 1759 and reprinted in Dublin in 1760; and was published in Cork under the new title Spectacles for Young Ladies; Exhibiting the various Arts made use of for seducing Young Women (Cork, 1767). Elizabeth Rowe, Devout Exercises of the Heart in Meditation and Soliloquy, Prayer and Praise (Newry and Dublin, 1762). Carter's admiration of Rowe as a precursor was restated each time her poem 'On the death of Mrs Rowe' was reprinted: see, for example, Rowe's Miscellaneous Works, 2 vols (London, 1739), I, cx-cxii; (London, 1749, 1750 and 1772), I, lxxix- lxxx; and (London, 1775), I, xxv-xxvi, all of which were published as by 'Elizabeth Carter'. We might also note here the biographical notice of Elizabeth Carter in the Belfast Monthly Magazine (1814), which picked up on an earlier magazine sketch in
} 
were also selling London imprints of bluestocking writings. ${ }^{56}$ Since Irish reprinted editions were less cautious about publicising the names of their Bluestocking authors - books by Aikin, Talbot, More and Carter were openly published under their names in Ireland when London editions remained anonymous - they are important in the history of the reception of the Bluestockings. Notably, for example, the Dublin reprint of Carter's Poems on Several Occasions (1777) not only named Carter on its title-page but also included a sketch of the author as a frontispiece. ${ }^{57}$ And the Cork edition of More's Works (1778) included a number of pieces which were associated with her much less directly in their London printings. ${ }^{58}$ Throughout the eighteenth century, women writers frequently signalled their authorship through signing a dedication within the book, a less ostentatious route than having their names printed openly on title-pages. ${ }^{59}$ The tendency of the Irish reprints to acknowledge authorship on their title-pages, rather than only in signed dedications, is a subtle difference

\footnotetext{
stressing the importance of her anti-Trinitarian views and named her as the author of a work of theological controversy in 1752, in ways which might be seen to address Belfast's dissenting community: compare The Monthly Magazine, 34 (1812), 108-109 and Belfast Monthly Magazine, 12.66 (1814), 27-35 (p. 33).

${ }^{56}$ One bookseller in Cork was selling works by Chapone, Carter and Talbot (and by Elizabeth Griffith, Catharine Macaulay and Sarah Fielding) in 1785: see Anthony Edwards, A Catalogue of Books, in Most Branches of Literature and Music [...] Now Selling by Anthony Edwards, no 3 Castle-Street, Cork (Cork: Printed for Anthony Edwards, 1785).

${ }^{57}$ Although Carter's dedication of her Poems on Several Occasions to the Earl of Bath had been openly signed in all the London editions (1762, 1766 and 1776), only the Dublin edition (1777) printed her name on the titlepage. (Similarly, Anna Laetitia Aikin's dedication was openly signed in the London editions, but only the Belfast printing included her name on its title-page.) The illustration of Carter in Poems (Dublin 1777) is taken from The Ladies Magazine, 3, (May 1772), 220 'Sketch of the Character of Mrs Carter'.

${ }^{58}$ The Works of Miss Hannah More in Prose and Verse (Cork, 1778). Notable here are this volume's Cork printings of the tragedy Percy, the Essays and a personal poem addressed to Garrick, the 'Ode to Dragon'. The first London editions of Percy (both 1778) and the play's first Irish editions (Belfast 1778; and Dublin 1778 and 1785) published the work anonymously (although advertisements in London editions of More's Essays in 1777 and 1778, themselves signed by More in the dedication, made this identification indirectly). London editions from the third edition (London 1780) included a signed dedication, but these post-dated the Cork edition of the Works. Similar to the case of Carter's Poems on Several Occasions, the Cork edition of her Essays (1778) - and the Dublin (1784) and Philadelphia reprints (1787) of her Sacred Dramas - printed More's name on their titlepages, while all London editions signalled her authorship only through a signed dedication. The only Irish edition of the Essays was that of Cork (1778; reprinted 1789). Lastly, the 'Ode to Dragon' was published anonymously in London, although it was advertised as 'by the same author' in the London edition of the Essays, a work which, as noted above, was acknowledged as by More in the signed dedication.

${ }^{59}$ However, all editions of Carter's Epictetus were published with her name on the title-page; and Chapone offers a second exception because all her works, excepting the first London and Dublin editions of Letters on the Improvement of the Mind (1773), were published with her authorship acknowledged on title-pages.
} 
but a notable one nevertheless. It certainly alters how we might consider the broader questions of Bluestocking fame.

Recent critical attention has turned to Elizabeth Carter's response to her considerable public reputation. Melanie Bigold, for example, has compellingly discussed how Carter drew upon manuscript and print forms in order to forge a consciously public identity. The printing of a miscellany of poems with Carter on its title-page is an important element of her renown, as the Irish reprints of Bluestocking writings are to the Bluestockings more generally. The 1770s mark the point at which a public awareness of the Bluestocking friends as a group of women begins to emerge. The first connections occur in texts which pair or group the friends together. The Westminster Review of 1773, for example, suggested that Carter, Montagu, and Hester Thrale might just as appropriately be given honorary doctorates as the usual list of political place-men. ${ }^{60}$ Chapone's Letters on the Improvement of the Mind (1773) were dedicated to Elizabeth Montagu as a testimony to their friendship, to remember that it was Montagu who encouraged her to publish the letters, and because Montagu's suggestions had allowed her to improve upon earlier drafts. Chapone's Miscellanies in prose and verse (London, 1775) were dedicated to Carter in a letter which extolled her private virtues of friendship as being greater even than the public acclaim she has enjoyed as a scholar. The two-volume Dublin edition of Chapone's collected Works (1775) then brought the three friends together by reprinting the dedications to Montagu and Carter at the outset of its two volumes. Since none of the London editions of Chapone's works printed the Letters and the Miscellanies together, this feature was distinct to the three Dublin editions $(1775,1777$, and 1786). ${ }^{61}$

\footnotetext{
${ }^{60}$ Westminster Review (July 1773), 408-9 'L.P.', 'On the Propriety of Bestowing Academical Honours on the Ladies'.

${ }^{61}$ Epilogues to two plays by Hannah More (A Search After Happiness and The Inflexible Captive, performed and printed between 1773 and 1775) praise Carter and Montagu and Aikin (Barbauld), among other women writers. The Monthly Review (April 1774), 243 followed suit in its notice of The Inflexible Captive in praising Carter, Montagu, Chapone, and Aikin, and the review was also excerpted in the London Chronicle (5-7 April
} 
Dublin reprints - in their more open naming of the Bluestocking women - thus had an important function to play in fostering and sustaining the idea of an exclusively female group of women writers. A further example is provided in comparing single-play editions of Hannah More's tragedy The Inflexible Captive (1773). Quickly going into four Bristol editions, it was the Dublin printing of the play which included a prologue by David Garrick in which Montagu, Carter and Aikin were openly named and cited together. ${ }^{62}$ In mapping the appearance of the Bluestockings in print, then, the Irish editions, and other 'regional' printings, need to be remembered as significant instances of print in their own right. ${ }^{63}$

The Dublin edition of Hester Chapone's Miscellanies (1775) is of further interest here because it extended the tradition of naming friends and associated women in a specifically Irish direction. The work opens with a letter to Elizabeth Carter, includes Chapone's 'Irregular Ode' to Carter and references Carter both openly and implicitly through a series of allusions to her poetry. ${ }^{64}$ The Dublin edition of Chapone's work introduces a new element which extends these links even more fully. In order to bulk out a volume, or perhaps to get rid of unsold stock, the Dublin publishers added their edition of David Fordyce's dream-vision, 'The Temple of Virtue' to that of Chapone's Miscellanies. Taking as their copy the second London edition of Fordyce's work (which includes the posthumous addition of a tribute to Queen Charlotte), they replaced the dedication of that work with one to Lady Arbella Denny,

1774). Examples of these textual linkings proliferate throughout the period c.1773-1800 and are too numerous to be cited here.

${ }^{62}$ Hannah More, The Inflexible Captive (Dublin, 1775), p. 52. The Dublin reprinting of the pastoral verse drama, The Search After Happiness (Dublin, 1773), however, did not include the epilogue in which Carter, Montagu and Aikin (among other women writers) were also celebrated together. This was added to the third Bristol edition: see Hannah More, The Search After Happiness (Bristol, 1774, $3^{\text {rd }}$ edn), p. 44.

${ }^{63}$ North American reprints of works by Bluestocking writers also tended to print authors' names on their titlepages: see, for example, those of More's Search after Happiness, Essays and Sacred Dramas (see note 58 above).

${ }^{64}$ Chapone's opening poem, 'Written during a violent Storm at Midnight, 1749' (pp. 103-104) may have inspired Carter's own 'Written at Midnight, in a Thunder Storm' (first published 1762); 'To Solitude' (pp. 119121) openly invokes Carter (see p. 120 and footnote); and the printing of poems by Metastasio, accompanied by Chapone's translations (pp. 124-137) follows Carter's practice in Poems (1762). 
as 'an affectionate votary of virtue'. ${ }^{65}$ If, then, as I have argued here, dedications and references to friends foster a public display of friendship, the Dublin edition extends the idea of a network to include other illustrious women. Lady Arbella Denny was well-known in Dublin circles for her philanthropic work on behalf of foundlings and reformed prostitutes and she had been made an honorary member of the Royal Dublin Society in 1766 because of her experimentation with silk worms, carpet weaving and damask manufacture. ${ }^{66}$ Less commonly known is that she also moved within Bluestocking circles in England. Elizabeth Carter writes to Vesey, for example, of having called upon her 'pretty often' in her visit to London of $1774 .{ }^{67}$ Indeed, the three women to be honoured by the Dublin Society - Lady Arbella Denny, Lady Bingham, and Lady Moira - were all personally known to the Bluestockings in England. ${ }^{68}$ Similarly, Ekaterina Dashkova, famous for her friendship with Empress Catherine the Great and renowned throughout Europe for her learning, visited Ireland in 1779-80, although Bluestocking letters indicate that Vesey met her in England in late $1776 .{ }^{69}$ The connections between learned women were therefore extensive, and while many of these women moved in the kinds of elite circles which permitted foreign or crosschannel travel, it also extended to women in the Bluestocking circle who were from relatively modest backgrounds, such as Carter, Chapone and More.

\footnotetext{
${ }^{65}$ [David Fordyce], The Temple of Virtue, a dream. Published by James Fordyce, D.D. Author of Sermons to Young Women. The second edition (Dublin: J. Williams, W. Wilson, and R. Moncrieffe, 1775); Miscellanies in prose and verse, by Mrs Chapone, Author of Letters on the Improvement of the Mind, To which is added, The Temple of Virtue, a dream (Dublin: J. Williams, W. Wilson, and R. Moncrieffe, 1775).

${ }^{66}$ See Rosemary Raughter, 'A natural tenderness: the ideal and the reality of eighteenth-century female philanthropy', in Women and Irish History: Essays in Honour of Margaret MacCurtain, ed. by M. G. Valiulis and Mary O'Dowd (Wolfhound Press, 1997), pp. 71-88.

${ }^{67}$ Carter, A Series of Letters (1809), IV, 106 (Carter to Vesey, 25 April 1774).

${ }^{68}$ For a reference to Lady Denny, see Carter, A Series of Letters (1809), IV, 106 (25 April 1774). For references to Lady Bingham, see Carter, A Series of Letters (1809), III, 342 (3 August 1768), IV, 46 (7 February 1772); IV, 109 (4 May 1774). For Lady Moira, see Vesey's letter to Elizabeth Montagu in which she recounts an extravagant masked ball in Dublin (28 April 1768): [The Elizabeth (Robinson) Montagu Papers] Vesey to Montagu, MO6283. The Vesey, Dawson and Bingham families were related and all commissioned the Waterford-born Thomas Roberts to paint landscapes of their county estates: see William Laffan and Brendan Rooney, p. 69. For the Dublin Society honours, see Mary O’Dowd, 'Politics, Patriotism, and Women in Ireland, Britain and Colonial America, c.1700-1780' in Journal of Women's History, 22.4 (Winter 2010), 15-38 (p. 22). ${ }^{69}$ Several of Vesey's letters to Montagu in 1776 refer to her meeting Dashkova in England, MO6265-6360. See also Carter, A Series of Letters (1809), IV, 170 (9 Dec 1776).
} 


\section{Conclusions}

From the surviving correspondence exchanged between Carter and her friends we can see how keenly they noted references to Carter in print. Allusions to Carter in Woman not inferior to man and in James Fordyce's Sermons to Young Women, the inclusion of poems by her in Poems by Eminent Ladies (1755), the sketch of her in Samuel's engraved print of 'The Nine Living Muses of Great Britain', and the translation into French of some of her poetry: all these are duly noted and discussed in Bluestocking letters. ${ }^{70}$ And because of the erratic survival of Carter's letters, we cannot absolutely rule out the possibility that she might have come to know of the Waterford book.

When Talbot had encouraged the younger Carter to permit some of her poems to be printed in Dodsley's Collection of Poems, Carter reply was forthright:

If I ever writ any thing worth printing, I should rather chuse to publish them myself than have them published by any body else. If I ever do appear in a Miscellany, I should chuse it should be in a Miscellany of Ladies. One may venture to say this with regard to the lady writers of the present age, though it would not have been much to one's credit perhaps in the last. $(5 \text { March } 1755)^{71}$

Bigold suggests that Colman and Thornton's Poems by Eminent Ladies (London 1755;

Dublin 1757) offered Carter just such a collection. ${ }^{72}$ But the comment also suggests that

\footnotetext{
${ }^{70}$ See Elizabeth Carter, 1717-1806: An Edition of Some Unpublished Letters, ed. by Gwen Hampshire (University of Delaware Press, 2005), p. 79 (Carter to Edward Cave, 1 December 1739); Carter, A Series of Letters (1809), III, 141 (Talbot to Carter, 23 August 1766) and II, 214-5 (Carter to Talbot, 22 December 1755); Memoirs (1807), p. 442 (Carter to Montagu, 24 August 1796). See also Vesey's letter to Montagu in which she claims to be jealous that she did not tell her of a 'new edition', a reference, if the date assigned to the letter is correct, to the third edition of Carter's Poems on Several Occasions (London, 1776): MO6265-6360.

${ }^{71}$ Carter, A Series of Letters (1809), II, 203 (Carter to Talbot, 5 March 1755).

72 See Bigold, pp. 173-5 and 195. Bigold omits, however, a reference to Carter's explicit objection to Poems by Eminent Ladies: see Carter, A Series of Letters (1809), II, 214-5 (Carter to Talbot, 22 December 1755).
} 
Carter might not have disapproved of the printing of her poetry in the Waterford Select

Poems. The collection is dominated by female-authored works, many of which are openly dedicated to female friends; advocates for the satisfactions of a virtuous, pious life; and aims to improve and enrich the experiences of the young ladies whom it so obviously addresses.

Works specifically addressed to young women were increasingly common in the later eighteenth century. James Fordyce's Sermons to Young Women (1766) went into at least 30 editions by 1800 (6 of them printed in Dublin); Oliver Goldsmith's compilation of Poems for young ladies (1767) openly cited Fordyce's Sermons as its inspiration and anticipated the Waterford collection in its intention to offer its female reader what will 'strengthen [her] innocence', so that 'while she courts only entertainment, [she will] be deceived into wisdom' ${ }^{73}$ While miscellanies for a female audience had been common throughout the eighteenth century, what was new was, as Carter's letter to Talbot suggests as early as 1755 , the way in which such collections had turned from amatory, even libertine, topics to a new trend for moral instruction. ${ }^{74}$ And the address to young readers was to become a particular feature of Bluestocking writings and how they were promoted. Hester Chapone's letters originally written to her niece were published as Letters on the Improvement of the Mind, Addressed to a Young lady (London and Dublin, 1773). Hannah More's plays and essays arose out of her experience of teaching at her sisters' girls' school in Bristol and were thus both explicitly addressed to young readers and promoted as written 'by a young lady' ${ }^{75}$

\footnotetext{
${ }^{73}$ Poems for Young Ladies (London, 1767), p. iii. Note also Edward Moore's New Fables invented for the Amusement of Young Ladies (London, 1749; Dublin, 1754), three of which were written by the Irish writer Henry Brooke. As noted above, Fordyce's Sermons included a complimentary allusion to Carter: see James Fordyce, Sermons for Young Women, 2 vols (1765; London, 1766), I, 202-3.

${ }^{74}$ See Laura Mandell, Misogynous Economies: The Business of Literature in Eighteenth-Century Britain (The University Press of Kentucky, 1999), p. 27. Barbara Benedict, The Making the Modern Reader: Cultural Mediation in Early Modern Literary Anthologies (Princeton University Press, 1996), p. 112 n. 14 notes that an ESTC search reveals a proliferation of miscellanies for female readers between 1718-1732 and 1770-1800 in particular: these titles broadly support the argument of a change in female-oriented miscellanies across the century.

${ }^{75}$ Hannah More, Essays on Various Subjects, principally designed for Young Ladies (London, 1777); Sacred Dramas: chiefly intended for young persons, the subjects taken from the Bible (London, 1782). More's A Search After Happiness (Bristol and Dublin 1773) noted in an accompanying advertisement that it had been composed
} 
Chapone explained in the Dedication to Carter of her Works that the poems published therein were mostly written when she was very young. ${ }^{76}$ And works by Chapone and More were printed with title-page epigraphs which stressed the importance of education. ${ }^{77}$ In Ellenor Fenn's School Occurrences (1783), the library of the school includes essays by Talbot and Chapone, poems by Carter and meditations by Talbot. ${ }^{78}$ Although not a conscious strategy, Bluestockings would probably have endorsed the applications of their writings to an audience of young female readers. They might therefore be seen as contributing to the broad turn by which women writers become pre-eminent in this branch of the print market. The Waterford collection was an early augury of this turn.

Irish editions of Bluestocking writings thus reflected both the full range of genres published - poetry, essays, drama, didactic chapbooks, literary criticism, and translation and the increasing adaptation of these works for a specifically young audience. They publicised the identities of the Bluestockings more readily than their English counterparts; they linked Bluestocking writers together in ways not present in the London editions; and they could also present Bluestocking writing in new ways. They therefore contribute significantly to the narrative of how the famously 'private' group of female friends became well-known, even proverbially so, as the Bluestockings.

when the author was 18 and that it had been often recited 'by a party of young Ladies', aged between 8 and 15 years old. See also the later American edition: Search After Happiness [...] As Performed by some young ladies of Bristol in England; Also, at the academies in Massachusetts (Worcester MA, 1797). The work went into twelve editions in Bristol and London by 1800 because of this appeal to girls' schools.

${ }^{76}$ Chapone, Works (Dublin, 1775), II, ii.

${ }^{77}$ Chapone's Letters on the Improvement of the Mind (London and Dublin, 1773) carried a long quotation on the benefits of education from the Spectator, 215 (6 November 1711) as its title-page epigraph and the Cork edition of More's Works quoted from Pope: 'Tis Education forms the tender Mind, / Just as the Twig is bent, the Tree's inclin'd': The Works of Miss Hannah More in Prose and Verse (Cork, 1778).

${ }^{78}$ [Ellenor Fenn], School occurrences, supposed to have arisen among a set of young ladies, under the tuition of Mrs Teachwell; and to be recorded by one of them (London, [1783]), p. 67. See also an episode in which the girls discuss why Miss Worthy's mother does not request that her daughter be taught to read Miss Carter's poems aloud, since Carter is such a modest poet. Miss Worthy replies that her mother is opposed to girls reading poetry aloud in general (p. 90). 
The Bluestockings were not, of course, the only famously learned ladies of the late eighteenth century, especially not in Ireland. Lady Arbella Denny, Lady Bingham, and Lady Moira were all known to the Bluestockings, but their fame as scholars had a distinctive Irish stamp: Lady Arbella Denny and Lady Bingham were elected honorary members of the Dublin Society (1766 and 1768 respectively), Lady Moira was honoured with a silver medal in 1774. In 1773 Poems by Eminent Ladies was retitled Poems by the most Eminent Ladies of Great Britain and Ireland in honour of its Irish inclusions. ${ }^{79}$ By the mid-1780s Charlotte Brooke's translations of poems from the Irish were being actively supported by members of the Royal Irish Academy; in 1791 Dashkova was elected honorary member of the Royal Irish Academy, the first woman to be so appointed. Mary O'Dowd's work on female education indicates a significant growth in girls' schools and a keen interest in female education in late eighteenth-century Ireland, evidenced, notably, in the early 1770s in the pages of Walker's Hibernian Magazine and the writings of Samuel Whyte. ${ }^{80}$ All of this points to a context in which the learned woman is not solely a 'Bluestocking' phenomenon, although the gathering fame of the Bluestockings certainly contributes to the cultural significance and, even, acceptability of female learning from the 1770 s onwards. ${ }^{81}$

The most consistent motif of the letters exchanged by Carter and Vesey is the way in which they imagine sharing each other's company, viewing the same landscapes,

\footnotetext{
${ }^{79}$ Poems by Eminent Ladies (London, 1755; Dublin, 1757); Poems by the most Eminent Ladies of Great Britain and Ireland (London, 1773; London, c.1785). Because the collection was arranged alphabetically, all editions opened with a selection from Mary Barber, followed shortly by poems by Constantia Grierson; poems by Laetitia Pilkington and Mary Monck followed in the second volume (and, in the final revised edition, Frances Greville's famous 'Prayer for Indifference'). Biographical head-pieces to the selections (1755, 1757 and 1773) and Colman and Thornton's companion essay to the anthology also made the Irish nationality of these authors obvious: see The Connoisseur. By Mr Town, Critic and Censor-General. Volume the Second (London, 1755; $3^{\text {rd }}$ edn), p. 266.

${ }^{80}$ See Mary O’Dowd, A History of Women in Ireland, 1500-1800 (Pearson, 2005), pp. 210-220. Relevant essays include: [Samuel Whyte], 'On Female Education' in Walker's Hibernian Magazine (May 1772); 'A Copy of a Letter, on a Proper Education for Young Ladies' in Walker's Hibernian Magazine (October 1774); Samuel Whyte, Modern Education [...] With Particular Proposals for a Reformation. In the Course of Which the Female Right to Literature is Asserted (Dublin, 1775).

${ }^{81}$ This is not to diminish the strength of continuing objections to female learning, not least those directed against the Bluestockings themselves. See Haslett, 'Bluestocking Feminism Revisited'.
} 
experiencing the same thrills, despite their geographical separation. In this regard, the connection made through personal correspondence mirrored that of the printed editions of Bluestocking writings, which linked London and Dublin; Lucan, Deal and Waterford; and Cork, Drogheda and Belfast in important networks of affiliation and female learning. And these networks in turn occurred within contexts in which new honours and acclaim were being granted to female scholars, writers and philanthropists and in which a poem for a specifically young female audience could find itself printed almost simultaneously in Philadelphia and Waterford. Such transnational interest in female learning would continue into the nineteenth century: in the first decades, for example, Anna Maria Chetwood corresponded with her Irish friends and sisters-in-law Martha and Katherine Wilmot when they were visiting Dashkova near Moscow. Out of this Wilmot-Chetwood circle would emerge a novel which advocates for the female right to education and which invokes in its title the Bluestockings of the previous century. ${ }^{82}$ Blue Stocking Hall (1827) remains the only fiction to name the famous Bluestockings in its title, but its publication aptly testifies to the prominence of these women as symbols of an aspiration to female learning, in Ireland, Britain and beyond.

\footnotetext{
${ }^{82}$ The author of Blue Stocking Hall, on current evidence, was either Chetwood or her sister-in-law Alicia Wilmot: see Angela Byrne, 'Anonymity, Irish Women's Writing, and a Tale of Contested Authorship: Blue Stocking Hall (1827) and Tales of my Time (1829)' (forthcoming). I am grateful to the author for sharing a prepublication version of this essay with me.
} 